\title{
Düyek Usûlünde, Rast ve Sabâ Makamlarındaki Şuğullerin Makam ve Güfte Analizi*
}

\author{
The Composition and Lyrics Analysis of Duyek Styled Suguls in Saba and Rast \\ Maqams
}

\section{Kadir İnan}

Öğr. Gör., Atatürk Üniversitesi Türk Mûsikîsi Devlet Konservatuarı, kadir.inan@atauni.edu.tr

\section{Özgür Sadık Karataş}

Doç. Dr., Atatürk Üniversitesi Güzel Sanatlar Fakültesi Müzik Bilimleri Bölümü, ozgursadik.karatas@atauni.edu.tr

*Bu çalışma "Düyek Usûlünde, Rast ve Sabâ Makamlarındaki Şuğullerin Makam ve Güfte Analizi” isimli Yüksek Lisans Tezi'nden türetilmiştir.

\section{$\ddot{O} \mathbf{z}$}

Bu çalışma, Klâsik Türk Mûsikîsi sözlü eserleri kapsamında Dinî Mûsikî alanındaki Arapça güfteli İlâhîler olarak bilinen Şuğullerin, beste ve güfte bağlamında incelenmesi ve müzikal analizlerinin yapılması amacını taşımaktadır. Bu noktadan hareketle çalışmamızda; Dinî Mûsikî sözlü eserlerinden olan Şuğullerin makamsal seyir özellikleri tespit edilmiş, güfte yapıları incelenmiş, güftelerin anlamları ele alınmıştır.

Araştırmada "Betimsel" yöntem kullanılmıştır. Betimsel yöntem kapsamında yer alan "Tarama" (Survey) modelinden yararlanılmıştır. Araştırma konusuna yönelik olarak kullanılan bu teknikler aracıllı̆̆ ile elde edilen tüm veriler analiz edilmiş ve yorumlanmıştır. Ayrıca araştırmanın evreni ve örneklemi kapsamında analiz edilen iki farklı makamdaki Şuğullerin tespiti için "Kota Örnekleme Yöntemi” kullanılmıştır.

Bu araştırmanın evrenini Klâsik Türk Mûsikîsi Dinî formlarında bestelenmiş sözlü eserler, çalışmanın örneklemini ise Rast (16) ve Sabâ (3) makamlarında bestelenmiş Düyek usûlünde olan on dokuz adet Şuğul oluşturmaktadır.

Araştırmanın birinci bölümünde, Klâsik Türk Mûsikîsi hakkında genel bilgiler verilmiş, Dinî Mûsikî sözlü eserlerinden olan Şuğuller üzerinde durulmuştur. İkinci bölümde araştırmanın yöntemi hakkında bilgi verilmiştir. Araştırmanın üçüncü bölümünde çalışmamızın konusu olan Rast ve Sabâ makamındaki Şuğullerin beste ve güfte yapıları analiz edilmiştir. Dördüncü bölümde, incelen Şuğuller üzerinde tespit edilen güfte ve yazım yanlışlıkları gibi sonuçlar üzerinde durulmuştur. Bunun yanı sıra Şuğullerin makamsal seyir özellikleri ve güftelerin vezin yapıları üzerinde tespit edilen sonuçlar belirtilmiştir.

Anahtar Kelimeler: Klâsik Türk Mûsikîsi, Türk Dinî Mûsikîsi, Şuğul, Makam, Güfte

\begin{abstract}
In this study, it is aimed to analyze Suguls known as Arabic Ilahis in the field of religious music within the context of Classical Turkish Musical oral works in the terms of composition and lyric. In the study,
\end{abstract}


the qualitative aspects of the Suguls of the religious musical works were determined, the structures of the lyrics were examined and the meanings of the lyrics were discussed.

The "descriptive" method was used in the study. The "Survey" model within the scope of the descriptive method was also used. All data obtained through these techniques used for the research topic were analyzed and interpreted. In addition, "Quota Sampling Method" was used for the determination of the Suguls in the two different agencies analyzed within the scope of the researcher's sample.

The universe of this study is composed of verbal works composed in Classical Turkish Musical Religious Forms and the sample of the study constitutes nineteen Suguls which are composed in Rast (16) and Saba (3) maqams.

In the first part of the study, general information about Classical Turkish Music is introduced and the focus is on Suguls, one of the works of religious music. In the second part, information about the research method is given. In the third part of the research, the compositions and lyrics of the Suguls of Rast and Saba have been analyzed. In the fourth part, the results such as lyrics and spelling mistakes that have been examined on Suguls are emphasized. In addition to this, the results of the determinations on the properties of the modals course features of Suguls and the measure structures of lyrics are mentioned.

Key Words: Classical Turkish Music, Turkish Religion Music, Sugul, Maqam, Lyrics

\section{Giriş}

İnsanoğlu, tarihsel süreç içerisinde yaşadığı tüm olayları; mûsikî, resim, heykel, edebiyat, mimari gibi sanatın farklı dallarında anlatmıştır. Mûsikî şüphesiz, insanların acı tatı tüm zamanlarında duygularını anlattığ bir sanat olarak var olagelmiştir.

İlkel toplumlardan itibaren mûsikînin, dinî törenlerde veya bazı din adamları tarafindan kötülüklerden korunmak, kutsanmak veya ibadet gibi maksatlar için kullanıldığı bilinmektedir. İşte bu bağlamda dinî mûsikî kavramı ortaya çıkmış ve tarih boyunca çeşitli merhalelerden geçerek günümüzde sistemli ve kurallı bir sanat haline gelmiştir.

Klâsik Türk Mûsikîsi, Dinî ve Din-dışı mûsikî alanlarında sayısız ve eşsiz eserlerin ortaya çıktığı, Türk kültürünün derin bir hazinesi olmuştur.

“Türk Din Mûsikîsi, 2500 yıllık Türk Mûsikîsi’nin iki ana şubesinden birini teşkil etmektedir. Diğer şube olan Lâ-Dinî Türk Mûsikîsi'nden, güfte, tavır, form vb. gibi yönlerden ayrılan ve kısaca; "Türkler'in, kendi dinî yaşayışlarıyla İslam'ı uzlaştırmaları sonucu ortaya çıkardıkları bir mûsikî çeşidi demek olan Türk Din Mûsikîsi'nin daha geniş bir tanımı şöyle yapılmaktadır: Hz. Peygamber (S.A.V.) ve sahabenin tatbikatı ile İslâm tasavvufunun görüşleri doğrultusunda ortaya çıkan Türklerdeki dini hayat, zamanla camîlerde, tekkelerde ve çeşitli tarikat toplantılarında yapılan ibadet ve zikir esnasında, birtakım vesilelere binaen ve çeşitli kaideler çerçevesinde icra edilen bir mûsikîyi meydana getirmiş, buna da Türk Din Mûsikîsi adı verilmiştir” (Demirtaş, 2009, s. 213-214).

Klâsik Türk Dinî Mûsikîsi'nde Tekke Mûsikîsi başlığı altında yer alan Şuğuller, Arapça güfteli İlâhîler olarak bilinmektedir. Konuları tasavvuf ve dinî içerikli olup, Hz. Peygamber'e ve Allâh'a olan aşk ve övgüler işlenmiştir. Şuğullerin ilk olarak ne zaman bestelendiği hakkında bir bilgi mevcut değildir. "Şuğul, Türk Din Mûsikîsi’ndeki yerini yaygın bir şekilde XIX. asrın ortalarında almış ve aynı asrın 
sonlarına doğru iyice gelişmiştir. Şuğul metinleri ile ilgili kaynaklar da bu asırda yazılmaya başlanmıştır” (Altıntop, 1994, s. 7).

Çalışmaya konu olan Şuğullerin makam ve güfte incelemelerine geçmeden önce Klâsik Türk Mûsikîsi'ne ait bazı başlıklara değinmekte fayda olduğu düşünülmektedir.

\section{Klasik Türk Mûsikîsi’nde Beste Türleri}

'Dünyanın her çeşit edebiyatında, Doğu'da olsun, Batı'da olsun, nasıl, zaman içinde oluşmuş, yazar veya şairlerin kurallarına uymak durumunda bulundukları edebî kalıplar varsa, çeşitli müziklerde de yine zaman içinde oluşmuş, bestecilerin ilhamlarını ses sanatına dökerken uymak durumunda bulundukları beste kalıpları vardır. Bu kalıpların adına genel olarak -Fransızcadan aldığımız bir terimle'form' diyoruz." (Tanrikorur, 2003, s. 47).

Klâsik Türk Mûsikîsi’nde formları Özkan (2010) şöyle belirtmiştir:

“Türk Mûsikîsi’nde formlar önce ikiye, sonra da yine kendi aralarında çeşitli şekilde ayrılırlar:
A. Saz mûsikîsi (Enstrumental müzik)
B. Sözlü mûsikî (Vokal müzik)" (s. 96).

\subsection{Saz Mûsikîsi Formları}

"Yalnız müzik aletleri ile icra edilmek üzere bestelenmiş sözsüz eserlerdir. Ölçü (usûl) ile veya ölçüsüz olarak serbest (doğaçlama) yapılır” (Çakar, 2004, s. 28).

\subsection{Söz Mûsikîsi Formları}

"Saz eşliğinde veya eşliksiz, belli bir güftenin insan sesiyle ve melodiyle okunması için meydana getirilmiş, makam veya makamlara bağl1, usûllü veya serbest eserlerdir. Şüphesiz ki sözlü formlar da bir takım biçimsel kaidelere bağlıdır. Dinî ve dindışı sözlü mûsikî diye ikiye ayrılır” (Özkan, 2010, s. 100).

Dinî mûsikî formları kendi arasında Câmî Mûsikîsi ve Tekke Mûsikîsi olmak üzere iki guruba ayrılır. Araştırma konusunu teşkil eden Şuğul tekke mûsikîsi formlarından biridir (Akdoğan, 2010, s. 200).

\section{Klâsik Türk Mûsikîsi'nde Usûller Hakkında Genel Bilgiler}

"Değerleri birbirine eşit olan veya olmayan belirli sınırlar içinde sıralanan mûsikî nağmelerini ölçmeye yarayan vuruşların bütününe usûl denir. Bu tarife göre, bir usûl birçok vuruştan meydana gelir. $\mathrm{Bu}$ vuruşlar belirli değerde mûsikî zamanlarını ölçmek için kullanılmaktadır. Bu zamanların değerleri birbirine eşit olsa da olmasa da sınırları mutlaka belirli ve vuruşları ölçülüdür” (Karadeniz, 2013, s. 30).

“Türk Mûsikîsi'nde usûller önce Basit ve Mürekkeb (Birleşik) oluşları bakımından ikiye ayrılırlar. Basit usûller, birleşimine başka hiçbir usûl girmemiş olan usûllerdir ki, iki zamanlı Nîm Sofyan usûlü ile üç zamanlı Semâi usûlünden başka Türk Mûsikîsi’nde basit usûl yoktur. Bu iki basit usûl, diğer bütün usûllerin birleşimine girerler. Mürekkep usûller, birleşimine iki veya daha fazla usûllerin karıştığı usûllerdir ki, 4 zamanlı Sofyan usûlünden başlayarak bütün Türk Mûsikîsi usûlleri birleşik usullerdir.

Türk Mûsikîsi usûlleri, küçük veya büyük oluşlarına göre de ikiye ayrılırlar:

Küçük usûller: 2 zamanlıdan 15 zamanlıya kadar olan (15 zamanlı dâhil) usûller, küçük usûllerdir.

Büyük usûller: 16 zamanlıdan başlayarak büyüğe doğru giden diğer bütün usûller büyük usûllerdir" (Özkan, 2010, s. 609). 


\subsection{Klâsik Türk Mûsikîsi'nde Düyek Usûlü}

"Türk müziğinin küçük usûllerindendir ve eski zamanlardan beri pek rağbetle kullanılan bir usûldür. Sekiz zamanlı ve beş darplıdır. Bu güzel usûl, İlâhî formunda en ziyade kullanılan ölçü olup, Âyîn'i Şerîflerin muayyen kısımlarında, Tevşîh, Peşrev, Kâr, Beste, Oyun Havası ve bilhassa Şarkı formlarında da istîmal edilir, 8/4 Ağır Düyek mertebesi de sık kullanılır. Düyek, iki adet Sofyan'dan mürekkeptir" (Devellioğlu, 2012, s. 222).

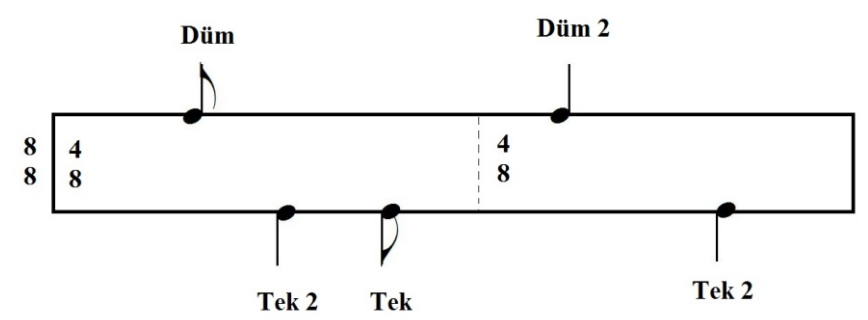

Şekil 1. Düyek Usûlü (Özkan, 2010: 633).

\section{Klasik Türk Mûsikîsi’nde Makamlar Hakkında Genel Bilgiler}

"Geleneksel Türk Mûsikîsi ezgileri makam sistemi ile ifade edilir. Orijinal bir yapıya sahip olan bu ezgiler, binlerce yılın süzgecinden geçmiş, yapıları sağlam ve tabiattaki her türlü sesi aksettirecek güçtedir. Türk Mûsikîsi ifade zenginliğini makam sistemi ile bulmuştur” (Kaya, 2003, s. 33).

Türk Mûsikîsi'nde makam; "Durak, güçlü ve yeden (bazı makamlarda kullanılmaz) sesleri ile belirlenen, belli bir melodik seyri olan, çeşitli ses kalıplarının birleştirilmesi ile meydana getirilen ezgisel bir yapıdır" (Aybars, 2011, s. 51).

"Makamlar, dörtlü ve beşlilerden oluşan çeşnilerin değişik şekillerde birbirlerine bağlanmasıyla ve bu çeşniler üzerinde gezinme hareketlerinden oluşur. Yani kısaca makam dizi+seyir demektir.

Makamlarımız seyir bakımından üç şekilde kullanılmıştır: 1) Çıkıcı, 2) İnici, 3) İnici-Çıkıcı" (Özkan, 2010, s. 115).

Yapı bakımından "Türk Mûsikîsi’nde makamlar üçe ayrılır:

a. Basit Makamlar

b. Şedd Makamlar (Göçürülmüş Makamlar)

c. Mürekkep Makamlar (Birleşik Makamlar)” (Özkan, 2010, s. 116).

\subsection{Rast Makamı}

Durağı: Sol (Rast) perdesidir.

Seyri: Çıkıcı bir seyir özelliğine sahiptir.

Güçlüsü: $\operatorname{Re}($ Nevâ) perdesidir.

Dizisi: Rast makamı, Yerinde Rast beşlisi ve Nevâ'da Rast dörtlüsünün birbirlerine eklenmesiyle meydana gelmiştir. 


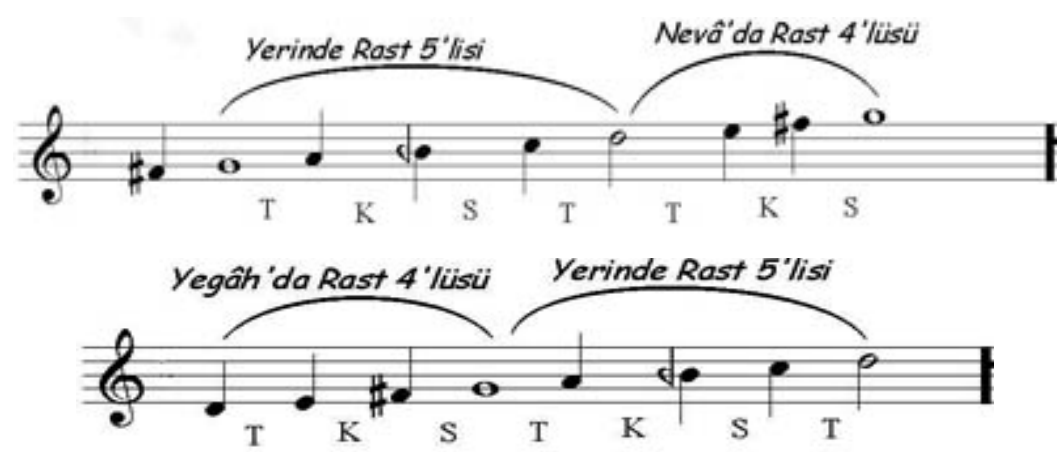

Şekil 2. Rast Makamı Dizisi

Donanımı: Si için koma bemolü (Segâh), Fa için bakiye diyezi (Eviç) donanıma yazılır.

Yeden: Sol (Rast) perdesidir.

Genişleme: Rast makamı çıkıcı ve ağır başlı bir makam olduğu için pest bölgelerde genişleme gösterir. Dolayısıyla Yegâh'ta Rast dörtlüsü ile genişlemektedir.

Seyri: Seyre, dizinin durak civarından veya durak altındaki genişlemiş bölgenin seslerinden başlayabilir. Dizide karışık gezinilerek Nevâ perdesinde yarım karar yapılır. Daha sonra Dügâh'ta Uşşâk, Segâh'ta Tam Ferâhnâk, Segâh'ta Eksik Ferâhnâk, Segâh'ta Tam veya Eksik Segâh, Hüseynîaşirân'da Uşşâk gibi gerekli olan asma kararlar ve bütün dizide hatta istenirse genişlemiş bölgede de dolaşıldıktan sonra Rast perdesinde çoğunlukla yedenli tam karar yapılır (Özkan, 2010, s. 137-139).

\subsection{Sabâ Makamı}

Durağı: La (Dügâh) perdesidir.

Seyri: Çıkıcı veya çıkıcı-inici bir seyir özelliği taşımaktadır.

Güçlüsü: Do (Çargâh) perdesidir. Çargâh’ta Zirgüleli Hicaz çeşnisiyle yarım karar yapılır.

Dizisi: Çargâh’ta Zirgüleli Hicaz dizisine yerinde Sabâ dörtlüsünün birbirine eklenmesiyle meydana gelmiştir.

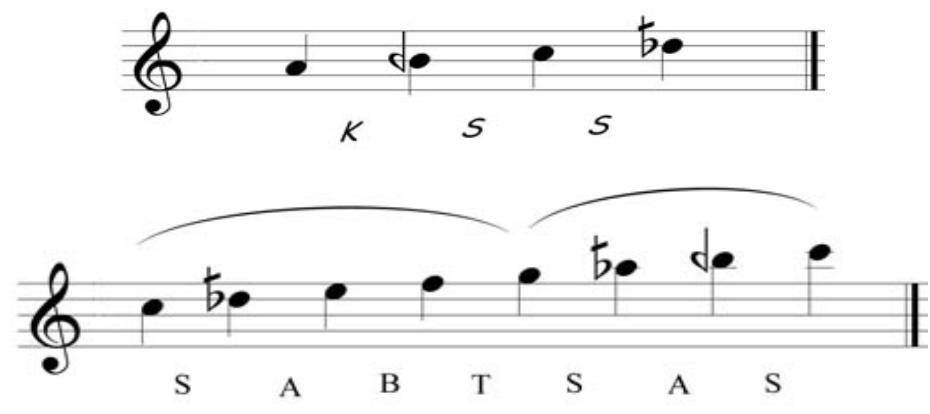

Şekil 3. Sabâ Makamı Dizisi

Donanımı: Si için koma bemolü (Segâh), Re için bakiye bemolü (Hicaz) perdeleri donanıma yazılır.

Yeden: Sol (Rast) perdesidir.

Genişleme: Sabâ makamı yapısı gereği geniş bir seyir alanına sahip olduğu için ayrıca genişletilmemiştir. 
Seyri: Seyre, güçlü perdesi olan Çargâh perdesi civarından bazen de durağı olan Dügâh perdesinden başlanır. Başta Çargâh perdesi olmak üzere diziyi oluşturan çeşnilerde ve bütün dizide karışık gezinilir. Daha sonra Acemde Nikriz'li, Dik Hisar'da Hüzzâm veya Segâh'lı, Segâh'ta Segâh'lı ve Rast'ta Rast'l1 çeşniler ve asma kararlar gösterilir. Nihayetinde güçlü olan Çargâh perdesinde Zirgüleli Hicaz çeşnili yarım karar yapılır. Ardından dizide yine karışık dolaşılarak Dügâh perdesinde Sabâ dörtlüsüyle tam karar yapılır (Özkan, 2010, s. 369-372).

\section{Problem Cümlesi}

Araştırmanın problem cümlesi, "Düyek Usûlünde, Rast ve Sabâ Makamlarındaki Şuğullerin Makam ve Güfte Analizi açısından sonuçları nelerdir?” olarak belirlenmiştir. Bu doğrultuda, problem cümlesine ilişkin iki alt problem saptanmıştır.

\subsection{Alt Problemler}

1. Klâsik Türk Mûsikîsi'nde Düyek usûlünde, Rast ve Sabâ makamlarındaki Şuğullerin genel yapıları ve makam yapıları açısından özellikleri nelerdir?

a. Klâsik Türk Mûsikîsi’nde Şuğul formunun ortaya çıkışı nasıldır?

b. Klâsik Türk Mûsikîsi'nde, Şuğuller bestelenirken hangi amaçlar hedeflenmiştir?

2. Klâsik Türk Mûsikîsi’nde Düyek usûlünde, Rast ve Sabâ makamlarındaki Şuğullerin makam ve güfte analizi açısından özellikleri nelerdir?

a. Klâsik Türk Mûsikîsi'nde Düyek usûlünde ölçülmüş Rast ve Sabâ makamlarındaki Şuğullerin makamsal analiz özellikleri nelerdir?

b. Klâsik Türk Mûsikîsi'nde Düyek usûlünde ölçülmüş Rast ve Sabâ makamlarındaki Şuğullerin güfte analiz özellikleri nelerdir?

\subsection{Araştırmanın Amacı ve Önemi}

"Düyek Usûlünde, Rast ve Sabâ Makamlarındaki Şuğullerin Makam ve Güfte Analizi” başlıklı bu araştırma, Şuğul formundaki eserlerin Klâsik Türk Mûsikîsi açısından güfte ve makam unsurlarını tespit etmeyi amaçlamıştır.

Klâsik Türk Dinî Mûsikîsi’nde önemli bir form olan Şuğullerin, bu çalışma kapsamında bestelenme unsurlarının analizi ve güftelerinin günümüz Türkçesine çevrilmesi, gelecekte bu konu üzerine araştırma yapacak olan müzisyen, araştırmacı ve akademisyenlere yol göstermesi ve onlara bu anlamda bir esin kaynağı olması amaçlanmaktadır.

"Düyek Usûlünde, Rast ve Sabâ Makamlarındaki Şuğullerin Makam ve Güfte Analizi” başlıklı bu araştırmada Şuğullerin bestelenirken makam, usûl, güfte ve mânâ gibi etkenler bakımından günümüzdeki beste yapımına etki etmesi açısından önemlidir.

\section{Yöntem}

$\mathrm{Bu}$ araştırmada betimsel araştırmalardan tarama modeli temel alınarak yürütülmüştür. "Betimsel Araştırmalar, olayı olduğu gibi araştıran ve ele alınan olayların ve durumların ayrıntılı bir biçimde araştırıldığ 1 ve onların daha önceki olaylar ve durumlarla ilişkilerinin incelenerek, ' $\mathrm{Ne}$ ' olduklarının betimlenmeye çalışıldığı araştırmalardır” (Karakaya, 2009, s. 59).

Betimsel araştırmaların bir türü olan 'Tarama Modeli' ise; geçmişte ya da halen var olan bir durumu, var olduğu şekliyle betimlemeyi amaçlayan araştırma yaklaşımlarıdır. Araştırmaya konu olan olay, birey ya da nesne, kendi koşulları içinde ve var olduğu gibi tanımlanmaya çalışılır. Onları herhangi bir şekilde değiştirme, etkileme çabası gösterilmez. Bilinmek istenen şey vardır 
ve oradadır. Önemli olan, ona uygun biçimde "gözleyip" belirleyebilmektir (Karasar, 2005, s. 77).

Tarama modeli kapsamında, yazılı literatür ve çeşitli veri kaynaklarından elde edilen verilerin içerik analizleri yapılmıştır.

\subsection{Evren ve Örneklem}

$\mathrm{Bu}$ araştırmanın evrenini Klâsik Türk Mûsikîsi Dinî formlarında bestelenmiş sözlü eserler oluşturmaktadır. Örneklemi ise 'Olasılık Temelli Olmayan Örnekleme Yöntemlerinden biri olan 'Kota Örnekleme' yöntemi ile oluşturulmuştur. "Olasılık temelli olmayan örneklemeler, özellikle nitel araştırmalarda kullanılan ve örneklemin küçük tutularak daha ayrıntılı bilgilere ulaşmanın amaçlandığı yöntemlerdir. Bunlardan 'Kota Örnekleme Yöntemi', sınırlı bir evrenin araştırmacının öngördüğü belirli değişkenlere göre araştırmanın amacına uygun şekilde sınırlandırıldığı, kotalandırıldığı bir yöntemdir” (Karakaya, 2009, s. 124).

Bu yöntem paralelinde; yapılan çalışmada incelenen Klâsik Türk Mûsikîsi sözlü eserlerinin, Dinî Mûsikî formlarındaki Şuğuller ile kotalandırılmıştır. Bu nedenle çalışmanın örneklemini, Düyek usûlünde olan Rast (16) ve Sabâ (3) makamında bestelenmiş olan on dokuz adet Şuğul oluşturmaktadır.

Tablo 1

Düyek usûlünde olan Rast ve Sabâ makamında bestelenmiş olan Şuğuller

\begin{tabular}{|c|c|c|c|c|c|}
\hline No & $\begin{array}{r}\text { Eser Adı } \\
\end{array}$ & Makamı & Usûlü & Güftesi & Bestesi \\
\hline 1 & Elà Yà Es'ade'l-'Evlàd & Rast & Düyek & Aziz Mahmud Hüdaî & Derviş Kanui \\
\hline 2 & El-Ḥamdü Lillāhi'llez̄ī Sulțanuhu Mūnžu'l-'Ezzel & Rast & Düyek & Ebû Bekir-İ Sıddıki & Hacı Faik Bey \\
\hline 3 & Eș-Șubḥu Bedā Min Ṭal'atibi & Rast & Düyek & $?$ & İmam-I Basri Hz. \\
\hline 4 & Feșaddaḳnāke Yā Hayra'l-Verā Yā Rasūlallāh & Rast & Düyek & $?$ & Sadettin Kaynak \\
\hline 5 & Hāżā ĠazālīMine'l-Yemānī Ve’ş-Şeklu'l-Ḥasen & Rast & Düyek & İmam Busûri & $?$ \\
\hline 6 & İn Nilte Yā Rīḥa'ṣ-Ṣabā Yevmen İle'l-'Erḍi'l-Ḥarem & Rast & Düyek & $?$ & $?$ \\
\hline 7 & İn Ṭāle Suḳmī Fi’l-Hevā' ve Meḍa'l-Ecel & Rast & Düyek & $?$ & $?$ \\
\hline 8 & Kum Yā 'Emīr'el-Gızlan Keyfe't-terāḥ & Rast & Düyek & $?$ & $?$ \\
\hline 9 & Li Hażreti’s-Seyyid Er-Rifā' & Rast & Düyek & $?$ & Eşşeyh Elhac Aşki Hz. \\
\hline 10 & Mā' Aleynā İz Veradnā Verteveynā & Rast & Düyek & $?$ & $?$ \\
\hline 11 & Mu'allā Ġāvṣ-i Sübḥānī & Rast & Düyek & Bahâeddin Efendi & Zekâi Dede Efendi \\
\hline 12 & Şera'ṭu Bi Tevḥīdi'l-lāhi Mübesmilen & Rast & Düyek & Abdülkâdir Geylâni Hz. & Hâfız Kemal Efendi \\
\hline 13 & Ve 'Ehsenü Minke Lem Tera Kaț̣ü 'Aynin & Rast & Düyek & Hasan B. Sabit & $?$ \\
\hline 14 & Yā Benī Bekrin (yā hū) Hubbukü Zādī & Rast & Düyek & $?$ & $?$ \\
\hline 15 & Yā Men Lațīfu Lem Yezel 'Ulțuf Binā F̄̄ Mā Nezel & Rast & Düyek & $?$ & Zekai Dede Efendi \\
\hline 16 & Yā Men Yuhịbbu 'Enīne'l-'Abdī Fī’n- Nedemi & Rast & Düyek & Hz. Ömer & Tanbûri Ali Efendi \\
\hline 17 & Fehüve Leyse Cismen Mā Terā & Sabâ & Düyek & $?$ & $?$ \\
\hline 18 & İn Nilte Yā Rịha’ṣ-Ṣabā Yevmen İle'l-'Erḍi'l-Ḥarem & Sabâ & Düyek & ? & Zekai Dede Efendi \\
\hline 19 & Cud Bi Luțfik Yā 'İlāhī Men Lehu Zādūn Kalīi & Sabâ & Düyek & Ebû Bekir-İ Sıddıki & Hacı Faik Bey \\
\hline
\end{tabular}

\subsection{Verilerin Toplanması ve Analizi}

$\mathrm{Bu}$ araştırmanın verileri, belgesel tarama yöntemi kullanılarak elde edilmiştir. "Var olan kayıt ve belgeleri inceleyerek veri toplamaya 'Belgesel Tarama Yöntemi' adı verilir. İki ayrı amaçla belgesel tarama tekniği kullanılır. Bunlar genel tarama ve içerik çözümlemesidir. 'Genel Tarama', araştırmacının araştırdığı konuda incelediği, okuduğu, çalışmasına aktardığı literatür taramasını içerir. 'İçerik Çözümlemesi' ise, belirli bir metnin, kitabın, belgenin belirli özelliklerini sayısallaştırarak belirleme amacıyla yapılan bir taramadır" (Karasar, 2005, s. 183-184). Bu çalışmada belgesel tarama yöntemlerinden genel tarama yöntemi kullanılmıştır.

Bu kapsamda çalışmaya yönelik tüm veriler, konuyla ilgili kaynak niteliğinde yayınlanmış olan kitapların, süreli yayınların ve ilgili eser notalarının taranması yoluyla toplanmıştır.

Bu çalışmanın ana unsuru olan "Düyek Usûlünde, Rast ve Sabâ Makamlarındaki Şuğullerin Makam ve Güfte Analizi” incelenmesinde en önemli analiz verileri, Klâsik Türk Mûsikîsi’nin günümüze ulaşan eserlerine ait notalarıdır. Şuğullere ait bu notalara TRT Repertuarı, Türkiye Cumhuriyeti Kültür 
Bakanlığı Arşivi, Devlet Korosu Arşivi ile özel koleksiyonların taranmasıyla ulaşılmış ve üzerlerinde analiz çözümlemeleri yapılmıştır.

Problem durumu ve alt problemlere ilişkin elde edilen veriler, 'Bulgular ve Yorum' kısmında analiz edilmiş ve yorumlanmıştır. Çalışmanın örneklemini oluşturan Rast ve Sabâ makamlarında bestelenmiş Şuğullerden Düyek usûlünde olan on dokuz adet Dinî Mûsikî bölümünden seçilmiş sözlü eserler beste ve güfte analizi yapılarak yorumlanmıştır.

\section{Bulgular ve Yorum}

Bu bölümde, araştırmanın iki alt problemine ilişkin elde edilen veriler analiz edilerek yorumlanmıştır. Birinci alt problem kapsamında; Klâsik Türk Mûsikîsi'nde Düyek usûlünde, Rast ve Sabâ makamlarındaki Şuğullerin makamsal seyri açısından bulgular ve yorumlara yer verilmiştir. İkinci alt problem kapsamında da; Klâsik Türk Mûsikîsi'nde Düyek usûlünde, Rast ve Sabâ makamlarındaki Şuğullerin makam ve güfte analizi açısından bulgular ve yorumlara yer verilmiştir.

\subsection{Birinci Alt Probleme İlişsin Bulgu ve Yorumlar}

Çalışmanın birinci alt problemi, “Klâsik Türk Mûsikîsi’nde Düyek usûlünde, Rast ve Sabâ makamlarındaki Şuğullerin genel yapıları ve makam yapıları açısından özellikleri nelerdir?” şeklinde belirlenmiştir. Birinci alt problem kapsamında, çalışmaya konu olan on dokuz adet Şuğul'ün beste analizleri ile elde edilen bulgular ve yapılan yorumlar açıklanmıştır.

1. Şuğul formu Klâsik Türk Mûsikîsi'nde Arapça güfteli İlâhîler olarak bilindiğinden müzikal olarak İlâhî formundan farklı bir özellik göstermemektedir. Bundan dolayı, Şuğullerin İlâhî formundan ayrı bir form olarak düşünülmemesi gerekmektedir. İlâhî ve Şuğul formunun çeşitli usûllerde bestelenmiş örnekleri mevcuttur. Ancak ritmik yapısını oyun havalarına benzetmemek için İlâhî tavrının dışına çıkılmaması gerekmektedir. İlâhîler; Dinî Mûsikî'de en çok okunan kısa, güzel ve akılda kalıcı nağmelere sahip formdur. Solo ya da toplu olarak okunmaktadır. Sözleri dinî ve tasavvufî içeriklidir.

2. Şuğullerin Klâsik Türk Mûsikîsi'ne ne zaman ve kim tarafından kazandırıldığına dair kesin bir bilgi kaynaklarda mevcut değildir.

3. Araştırmaya konu olan on dokuz adet Şuğul, Rast ve Sabâ makamlarındadır. Klâsik Türk Mûsikîsi repertuarına bakıldığında Şuğullerin daha çok basit makamlardan bestelenmiş örneklerinin olduğu görülmektedir. Bu durumun İlâhî formu için de geçerli olduğu söylenebilir.

4. Şuğuller form olarak uzun soluklu nağmelere sahip olmadığından genel seyir sırasında makam geçkileri az miktarda yapılmıştır. Bazılarında ise makam geçkisi yapılmamıştır.

5. Araştırmaya konu olan on dokuz adet Şuğul incelendiğinde, nağmelerin mûsikî açısından sanatlı olmasının yanı sıra akılda kalıcı ve anlaşılması güç olmayan nağme yapısına sahip oldukları görülmüştür.

\section{2. İkinci Alt Probleme İlişkin Bulgu ve Yorumlar}

Çalışmanın ikinci alt problemi, "Klâsik Türk Mûsikîsi'nde Düyek usulünde, Rast ve Sabâ makamlarındaki Şuğullerin makam ve güfte analizi açısından özellikleri nelerdir?" şeklinde belirlenmiştir. Buna göre, bu alt probleme ilişkin elde edilen bulgular kapsamında, araştırmaya konu olan on dokuz adet Şuğul'ün alfabetik sıraya göre beste ve güfte analizleri yapılarak, Arapça güftelerinin günümüz Türkçesi’ndeki anlamları üzerine bulgu ve yorumlara ilişkin bilgilere yer verilmiştir. 


\subsubsection{Klâsik Türk Mûsikîsi’nde Örneklem Olarak Seçilen Düyek Usûlünde, Rast Makamındaki Şuğullerin Makam ve Güfte Analizleri}

Çalışmanın ikinci alt problemi kapsamındaki bu alt başlıkta, Klâsik Türk Mûsikîsi’nde Düyek usulünde, Rast makamındaki Şuğullerin makam ve güfte açısından analiz edilmiş ve yorumlanmıştır. İncelenen Şuğullerin güfteleri Arap alfabesi harfleriyle yazılmış, transkripsiyon alfabesine göre Latin alfabesi harfleriyle de yazılmıştır. Ayrıca Arapça güftelerin günümüz Türkçesine çevirileri de yazılmıştır.

Araştırmada çalışmanın örneklemini oluşturan Rast (16) ve Sabâ (3) makamlarında bestelenmiş Düyek usûlünde olan eserlerden her bir makama birer örnek verilmiştir.

\section{RAST SUGGUL}

USÔL: DÜYEK
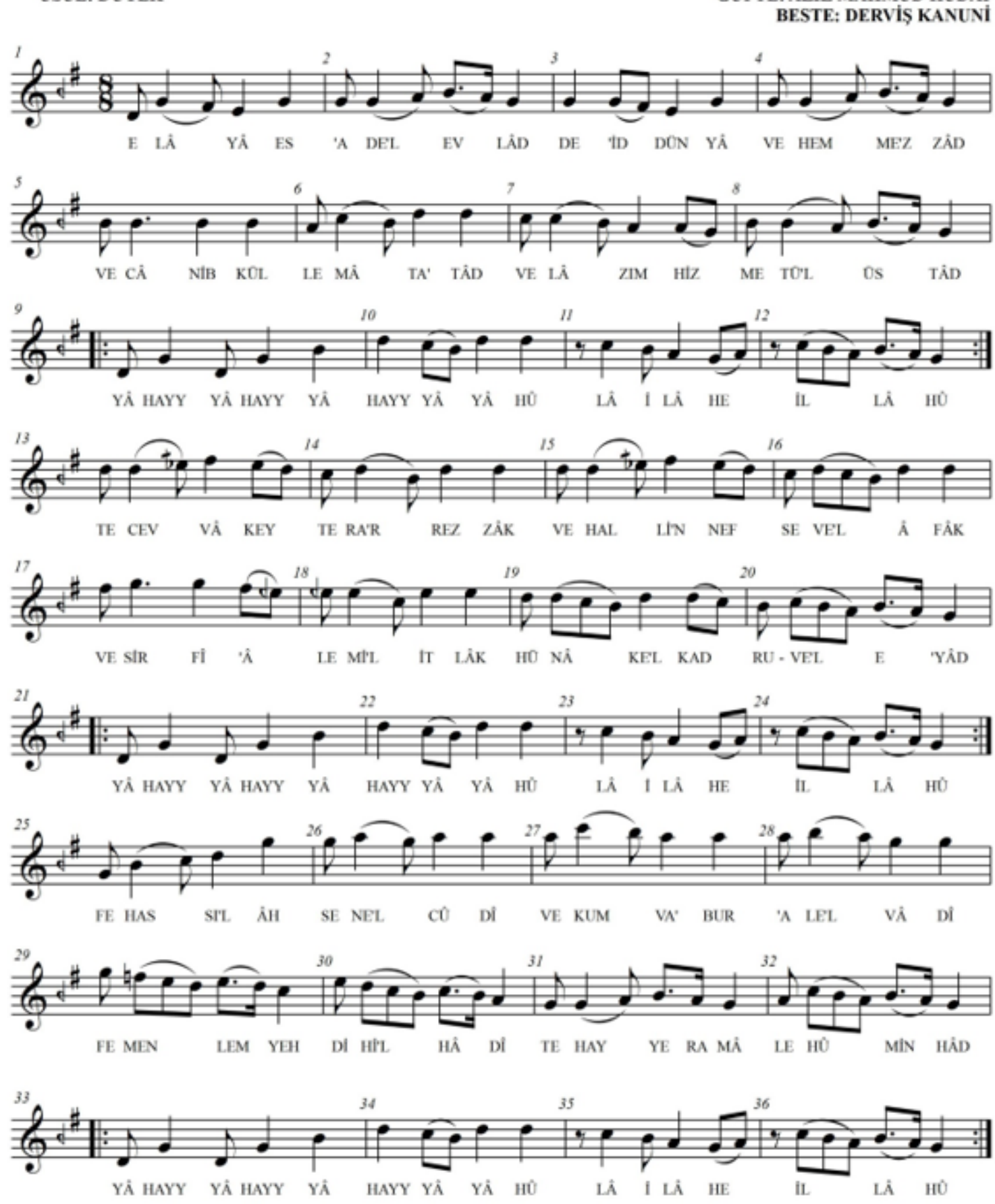

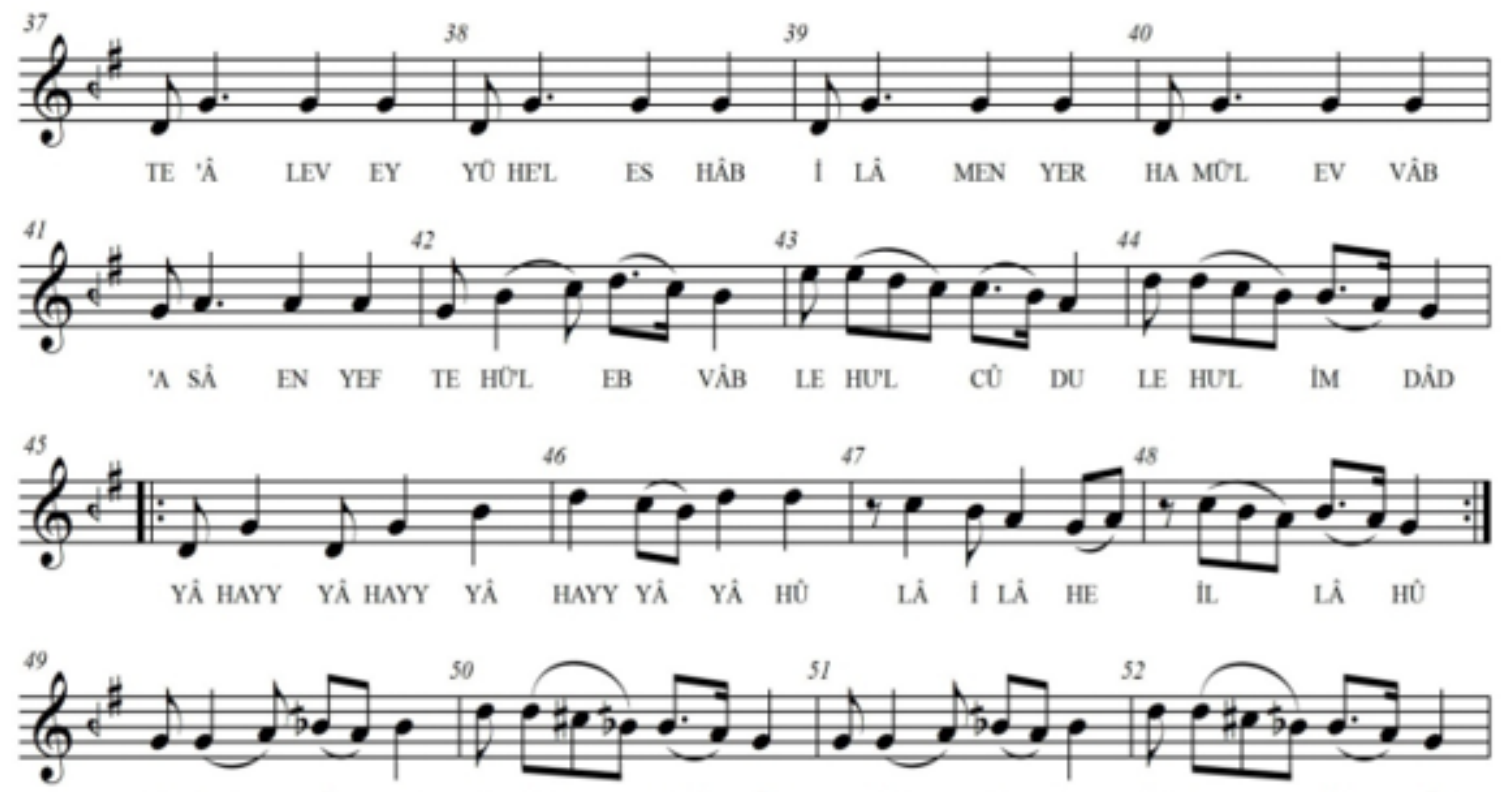

TE CEL Lỉ RAB BU NER RAH MÃN LE HUL FAZ LU LE HUL L IH SÃN
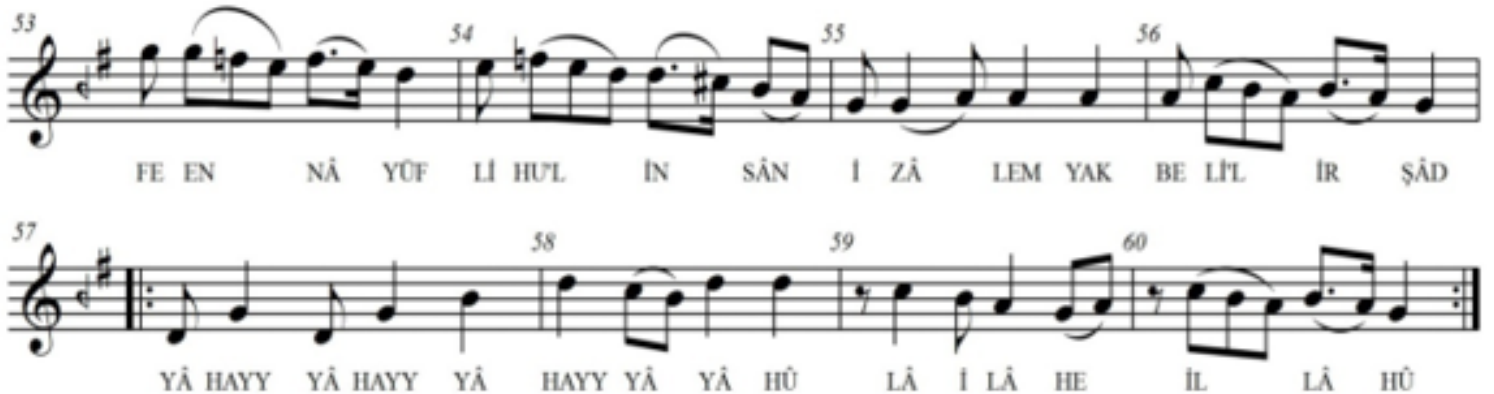

ELÂ YÂ ES'ADE'L-EVLÂD

DE'ID-DÜNYÂ VE HEMME'Z-ZẦ

VE CÂNIB KÛ̉LLE MÂTTA'TÂD

VE LÂZIM HIZMETÛ́'L-Ĉ́STÂD

YÂ HAYY YÂ HAYY YÂ HAYYYÂ YÂ HÛ

LÂ İLÂHE İLLÂHÛ

TECEVVÂ KEY TERÂ'R-REZZÂK

VE HALL'I'N-NEFSE VE'L-ÂFÂK

VE SIR FÎ 'ALEMI'L ITLÂK

HÛ̉NÂKE'L-KADR-U VE'L-E'YÂD

FEHASST'LÂHSENE'L-CÔDî

VE KUM VA'BUR 'ALE'L-VÂDí

FEMEN LEM YEHDIHI'L-HÂDî

TEHAYYERA MÂ LEHÛ́ MIN HÂD
TE'ÂLEV EYYŨHE'L-ESHÂB

İLÂ MEN YERHAMÛ'L-EVVÂB

'ASÂ EN YÜFTEHÛ̉'L-EBVÂB

LEHU'L-CUDÛ LEHU'L-IMDÂD

TECELLÂ RABBUNE'R-RAHMÂN

LEHU'L-FAZLU LEHU'L-IHSÂN

FE'ENNÂ YÜFLIHHU'L-INSẤN

IZÂA LEM YAKBELI'L-İRŞẨ

Resim 1. Elà Yà Es 'ade'l-'Evlàd

\section{“Elà Yà Es`ade’l-'Evlàd” Adlı Rast Şuğul'ün Makam Analizi}

Şuğul altmış ölçüden oluşmaktadır.

1. Ölçü: Rast makamının pest taraftan genişlemesi olan Yegâh perdesindeki Rast dörtlüsü ile seyre başlanmıştır.

2. Ölçü: Rast perdesinde asma kalış yapılmıştır. 
3. ve 4. Ölçü: Rast perdesi civarında seyir devam etmektedir.

5. Ölçü: Segâh perdesinde asma karar yapılmıştır.

6. Ölçü: Dügâh perdesi üzerinde Uşşak dörtlüsü gösterilip güçlü Nevâ perdesinde asma kalış yapılmıştır.

7. Ölçü: Rast beşlisi ile Rast perdesine inici özellikte bir seyir gösterilmiştir.

8. Ölçü: Rast perdesi civarında gezinilerek yine Rast perdesinde yarım karar yapılmıştır.

Dokuz, on, on bir ve on ikinci ölçüler Şuğul'ün nakarat bölümüdür.

9. Ölçü: Rast makamının pest taraftan genişlemesi olan Yegâh perdesinde Rast dörtlü ile seyir devam etmektedir.

10. Ölçü: Güçlü Nevâ perdesinde asma kalış yapılmıştır.

11. Öçü: Rast beşlisi ile Rast perdesinde asma karar yapılımıştır.

12. Ölçü: Rast perdesinde yarım karar yapılmıştır.

13. Ölçü: Nevâ'da Hicâz dörtlü gösterilmiştir.

14. Ölçü: Nevâ perdesinde asma kalış yapılımıştır.

15. Ölçü: Nevâ'da Hicâz dörtlü gösterilmiştir.

16. Ölçü: Nevâ perdesinde asma kalış yapılmıştır.

17. ve 18. Ölçü: Dik Hisâr perdesinde Müstearlı bir geçki ile Dik Hisâr perdesinde asma kalış yapılmıştır.

19. ve 20. Ölçü: Rast beşlisi ile Rast perdesinde yarım karar yapılmıştır.

21. 22. 23. ve 24. Ölçü: Nakarat bölümüdür ve yukarıda analizi yapılmıştır.

25. Ölçü: Rast perdesinden Gerdâniye perdesine bir oktavlık çıkış yapılmıştır.

26. Ölçü: Tiz Segâh perdesinde Segâhl1,

27. Ölçü: Muhayyer perdesinde Uşşâkl1,

28. Ölçü: Gerdâniye'de Rastlı asma kalışlar yapılmıştır.

29. Ölçü: Çargâh perdesinde Çargâhlı asma kalış yapılmıştır.

30. Ölçü: Dügâh perdesinde Hüseynîli asma kalış yapılmıştır.

31. ve 32. Ölçü: Rast perdesi civarında gezinilip Rast perdesinde yarım karar yapılmıştır.

33. 34. 35. ve 36. Ölçü: Nakarat bölümü olup yukarıda analizi yapılımıştır.

37. 38. 39. ve 40. Ölçü: Yegâh Rast atlaması yapılarak genişletilmiş pest bölge gösterilmiştir.

41. Ölçü: Dügâh perdesinde asma kalış yapılmıştır.

42. Ölçü: Segâh perdesinde asma kalış yapılmıştır.

43. Ölçü: Dügâh perdesinde Hüseynî beşlisi ile asma kalış gösterilmiştir.

44. Ölçü: Rast beşlisi ile Rast perdesinde asma kalış yapılmıştır.

45. 46. 47. ve 48. Ölçü: Nakarat bölümüdür ve yukarıda analizi yapılmıştır. 
49. Ölçü: Rast perdesinde seyre devam edilerek Dik Kürdi perdesi ile Hicâz vurgusu yapılmıştır.

50. Ölçü: Nikriz beşlisi ile Rast perdesinde asma kalış yapılmıştır.

51. Ölçü: Rast perdesinde seyre devam edilerek Dik Kürdi perdesi ile Hicâz vurgusu yapılmıştır.

52. Ölçü: Nikriz beşlisi ile Rast perdesinde asma kalış yapılmıştır.

53. Ölçü: Tiz durak Gerdâniye perdesinden Nevâ perdesine inilerek Bûselikli bir asma kalış gösterilmiştir.

54. ve 55. Ölçü: Nikriz beşlisi ile seyir devam edip Dügâh perdesinde asma karar verilmiştir.

56. Ölçü: Rast perdesinde yarım karar verilmiştir.

57. 58. 59. ve 60. Ölçü: Nakarat bölümü olup yukarıda analizi yapılımıştır.

60. Ölçü: Rast dörtlüsü ile tam karar yapılmıştır.

\section{“Elà Yà Es’ade'l-'Evlàd” Adlı Rast Şuğul'ün Güfte Analizi}

\section{a. Güftenin Arapçası}

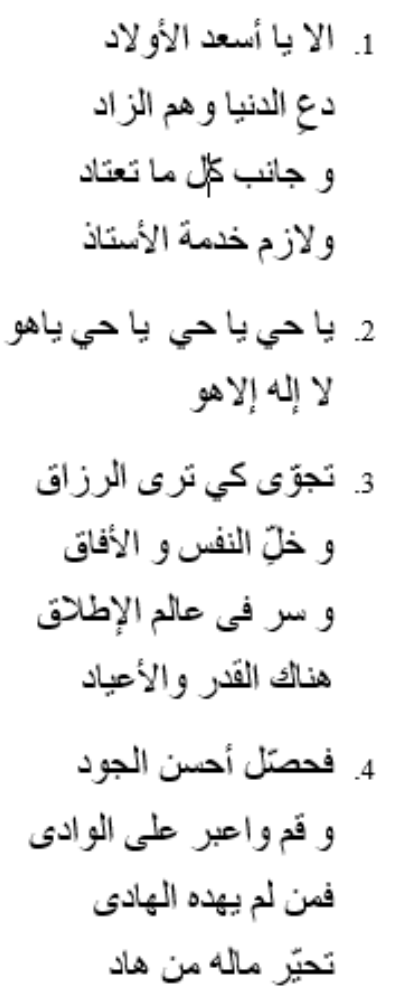




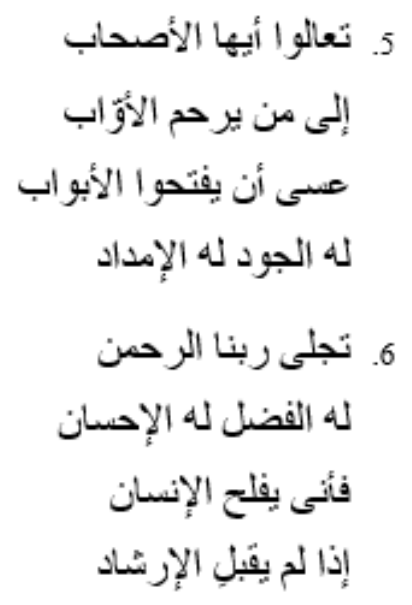

\section{b. Güftenin Transkripsiyonu}

1. Elà Yà Es 'ade'l-'Evlàd

De'id-dünyā ve hemme'z-żād

Ve cānib külle mā ta'tād

Ve lazım hizmetü'l-'üstād

2. Yā Hayy yā Hayy yā Hayy yā hū

Lā ilahe illa hū

3. Tecevvā key terā'r-rezzāk

Ve ḥalli'n-nefse ve'l-'āfâk

Ve sir fi 'ālemi'l-'iṭlāḳ

Hünāke'l-ḳadru ve'l-e' yād

4. Fehasss''l 'aḥsene'l-cūdī

Ve ḳum va'bur 'ale'l-vādī

Femen lem yehdihi'l-hādī

Tehayyer mā lehū min hād

5. Te'ālev eyyühe'l-eșḥāb

İlā men yerḥamü'l-'evvāb

'Asā 'en yeftehüu'l-'ebvāb

Lehu'l-cüdu lehu'l-'imdād

6. Tecellā rabbune'r-raḥmān

Lehu'l-fażlu lehu'l-'ị̣sān

Fe'ennā yüfliḥu'l-'insān

'İżā lem yaḳbeli'l-'irşād

\section{c. Güftenin Tercümesi}

1. Dikkat et ey çocukların en mutlusu

Bırak dünyayı ve geçim sıkıntısını

Bırak alıştı̆ı̆ın her şeyi

Devam et üstadına hizmetine

2. Ey her zaman diri olan

Allâh'tan başka ilâh yoktur

3. Kalpten yönel rızık vereni görmek için

Bırak enfüsü ve âfâk1 
Yürü özgürlük âleminde

Oradadır kadr ve bayramlar

4. Elde et en güzel azığı

Kalk ve geç vadiyi

Etmezse Allah kime hidayet

Şaşırır ve kimse edemez ona hidayet

5. Gelin ey dostlar

Çok tövbe edenlere merhamet edene

Umulur ki kapıları açar

Cömertlik ve yardım onundur

6. Tecelli etti Rahmân olan Rabbimiz

Ona aittir fazilet ve ihsân

Nasıl felâh bulur insan

İrşâdı kabul etmeyince

\section{d. Güftenin Vezni}

Şiir sekizli hece ölçüsü ile ölçülmüştür. 


\section{SABA ȘUĞUL \\ USÛ́L: DÜYEK \\ CUD Bi LUTFiK YÂ 'íLÂHî̉ MEN LEHU ZÂDŪN KALîL
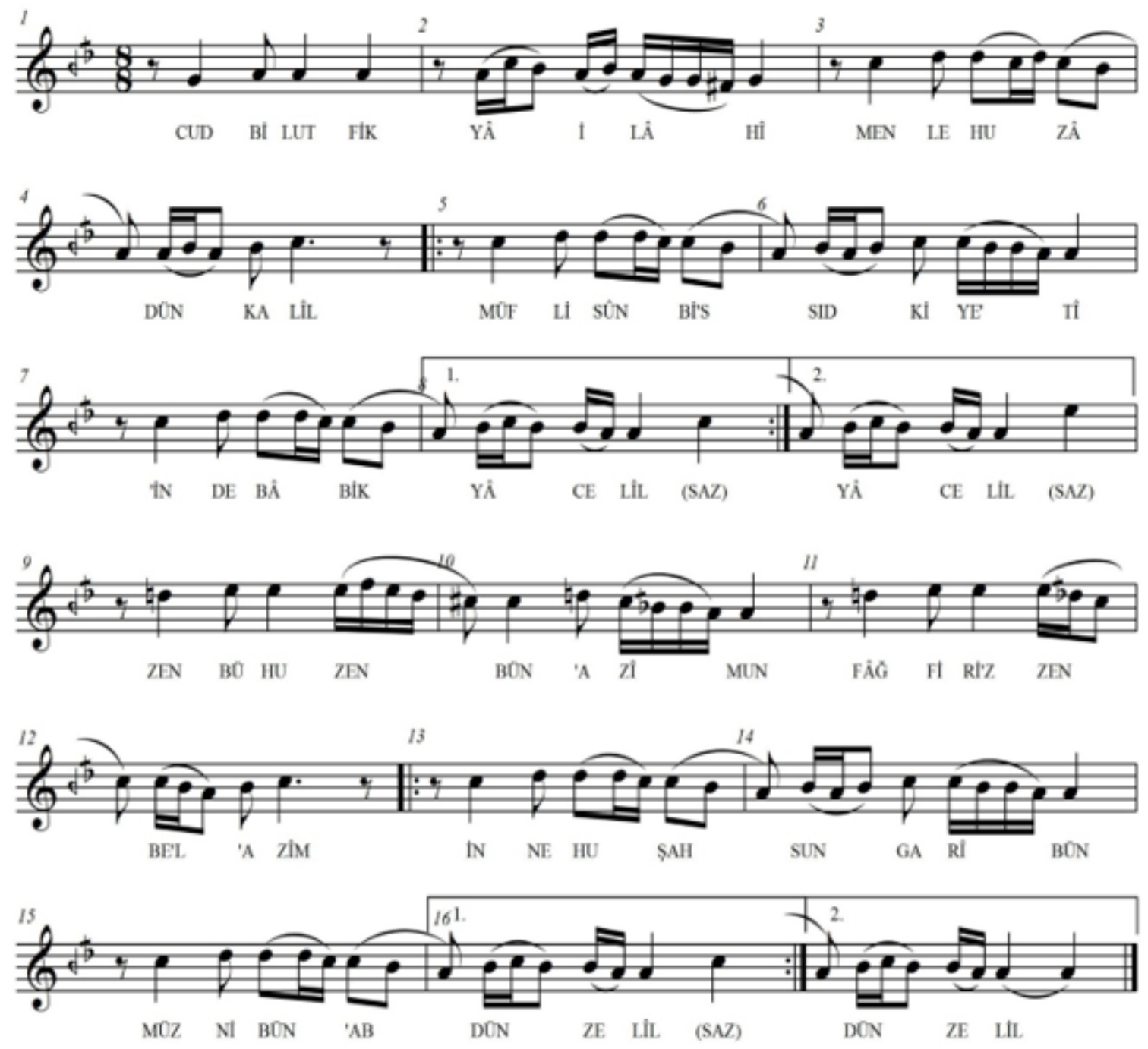

CUD Bỉ LUTFiK YÂ 'íLÂHÎ MEN LEHU ZÂDÜN KALîL

MÜFLISÛ́N Bi'S-SIDKI YE'Tí 'INDE BÁBíK YÂ CELÎ́L

ZENBÜHU ZENBŬN 'AZIMUUN FÂGFIRI'Z-ZENBE'L-'AZIM

INNEHU SAHSUN GARIBBÓN MOOZZNIBŌN 'ABDÓN ZELî́L

Resim 2. Cud Bi Lutfik Yā ‘ìlāhī Men Lehu Zādün Kal̄̄l

“Cud Bi Lutfik Yā 'İlāhī Men Lehu Zādün Kalīl” Adlı SabâŞuğul'ün Makam Analizi

Şuğul on altı ölçüden oluşmaktadır.

1. Ölçü: Karar perdesi civarından seyre başlanmıştır.

2. Ölçü: Sabâ dörtlüsü gösterilerek yeden Rast perdesinde asma kalış yapılmıştır.

3. Ölçü: Sabâ dörtlü ile seyir devam etmektedir.

4. Ölçü: Güçlü Çargâh perdesinde asma kalış yapılmıştır. 
5. Ölçü: Çargâh perdesinden seyre başlanıp Sabâ dörtlüsü gösterilmiştir.

6. Ölçü: Yerinde Sabâ dörtlüsü ile asma kalış yapılmıştır.

7. Ölçü: Güçlü Çargâh perdesinden seyir devam etmektedir.

8. Ölçü: Sabâ dörtlüsü gösterilerek güçlü Çargâh perdesinde yarım karar yapılmıştır.

9. Ölçü: Sabâ makamından Hicâz makamına geçiş yapılacağından Nevâ perdesi ile Rast üçlüsü gösterilmiştir.

10. Ölçü: Yerinde Hicâz dörtlüsü ile Dügâh perdesinde asma kalış yapılmıştır.

11. Ölçü: Sabâ makamına dönülerek Çargâh perdesinde asma kalış yapılmıştır.

12. Ölçü: Güçlü Çargâh perdesinde asma kalış yapılmıştır.

13. Ölçü: Çargâh perdesinden seyre başlanıp Sabâ dörtlüsü gösterilmiştir.

14. Ölçü: Yerinde Sabâ dörtlüsü ile asma kalış yapılmıştır.

15. Ölçü: Güçlü Çargâh perdesinden seyir devam etmektedir.

16. Ölçü: Dügâh perdesinde tam karar yapılmıştır.

“Cud Bi Lutfik Yā 'İlāhī Men Lehu Zādün Ḳalīl” Adlı Sabâ Şuğul'ün Güfte Analizi

a. Güftenin Arapçası

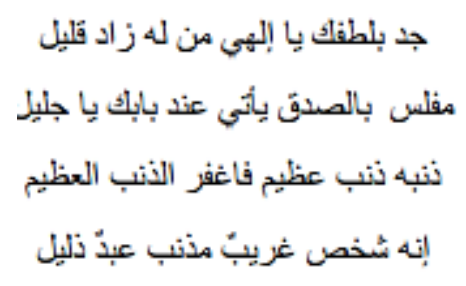

\section{b. Güftenin Transkripsiyonu}

Cud bi lutfik yā 'ilāhī men lehu zādün ḳalīl

Müflisūn bi’ṣ-ṣıdḳi ye'tî 'inde bābik yā celil

Zenbühu zenbün 'aẓīmun făgifiri' ż-ženbe'l-'aẓim

İnnehu şahșun garibün müznibün 'abdün zelīl

\section{c. Güftenin Tercümesi}

Yâ ilâhi! Azığı az olan şu garibe bol bol ihsanda bulun

Ey celil olan Allah'ım, iflas etmiş olan bu kulun sıdk ile kapına gelmiştir

Onun günahı çok büyük bir günahtır, sen o büyük günahı affet

O garip bir şahıstır, günahkârdır, zelil bir kuldur

\section{d. Güftenin Vezni}

Şiir âruz vezni ile ölçülmüştür.

Vezni: Fâ'ilâtün / Fâ'ilâtün / Fâ’ilâtün / Fâ'ilün 
Şiirin üçüncü mısrasındaki “Õenbühu õenbün” kelimelerinin 'hu' hecesi ile 'õen' hecesi arasında, dördüncü mısrasındaki "İnnehu şaóãun” kelimelerinin 'hu' hecesi ile 'şaó' heceleri arasında imâle vardir.

\section{Sonuç ve Öneriler}

\subsection{Birinci Alt Probleme İlişkin Sonuçlar}

1. Araştırmada örneklemdeki Şuğuller incelendiğinde, İlâhî formunun form yapısının dışına çıkılmadığı ve aynı yapıya sahip olduğu görülmüştür. Dolayısıyla Klâsik Türk Mûsikîsi’nde Şuğullerin Arapça güfteli İlâhîler olduğu sonucuna varılmıştır.

2. Şuğuller, İlâhîlerden sadece güftelerinin Arapça olması ile ayrılmaktadır. Güftelerin Arapça olarak seçilmesi bestekârların tercihi olduğu düşünülmektedir.

3. Şuğullerdeki Arapça güftelerin vezin yapılarının bozulmaması için Osmanlı Türkçesi'ne çevrilmediği düşünülmektedir. Bu durumun sonucu olarak da Şuğullerin, Klâsik Türk Mûsikîsi'ne yeni bir form olarak kazandırıldığı sonucuna ulaşılmıştır.

4. Şuğuller, İlâhî duyguların insanların gönüllerine yerleşmesine vesile olan tekkelerde, câmilerde ve dinî hislerin dile getirildiği çeşitli meclislerde icra edilmiştir. İnsanların bu sayede, Kur'an dili olan Arapça ile ortaya konmuş bu sanatlı mûsikî ile gönül evlerine köprü kurarak manevi zevklere ulaştığı düşünülmektedir.

5. Şuğullerin tekkelerde, çoğunlukla bayramlarda ve kandil gecelerini karşılayan ayin günlerinde okunduğu sonucuna ulaşılmıştır.

6. Şuğullerin özellikle Rifâi, Kādirî, Bedevî, Desûkī, Sa'dî tarikatlarına has bir tören olan nevbe merasimlerindeki kıyam zikri esnasında söylendiği bilinmektedir. Bu tören sırasında Şuğullerin; halîle, mazhar, kudüm gibi çalgılar eşliğinde İlâhîlerle beraber okunup, ağırdan başlayarak giderek süratlenen bir seyir takip edilerek icra edildiği sonucuna ulaşılmıştır.

7. Şuğuller günümüzde evlenme, sünnet, mevlid gibi çeşitli dinî meclislerde halen okunduğu, bunun yanı sıra dinî mûsikî ve tasavvuf mûsikîsi konserlerinde, çeşitli radyo ve televizyon programlarında da okunduğu sonucuna ulaşılmıştır.

8. Şuğul adının kim tarafından verildiği bilinmediği sonucuna ulaşılmıştır.

9. Şuğul formunun ilk olarak hangi tarihte Klâsik Türk Mûsikîsi'ne kazandırıldığının bilinmediği sonucuna varılmıştır.

10.Şuğullerin çoğunlukla Düyek ve Sofyan usûllerinde bestelendiği tespit edilmiştir. Düyek ve Sofyan usûlleri İlâhîlerde de sık kullanılan usûllerdir. Bu usûllerin aksak olmayışı ve darplarının kolay vuruluşu Şuğullerin öğrenilişini de kolaylaştırdığı sonucuna varılmıştır.

11.Günümüze ulaşan yaklaşı üç yüz kadar Şuğul vardır ve en çok Şuğul besteleyen sanatkârın otuz altı Şuğul bestesi ile Hoca Mehmed Zekâî Dede Efendi olduğu sonucuna ulaşılmıştır.Şuğullerin, öğrenenlerin zorlanmadan okuması ve okunduğu zaman bilmeyenler tarafindan çabuk öğrenilebilmesi için akılda kalıcı ve kolay anlaşılır olan makamlarda bestelendiği düşünülmektedir. Bundan dolayı Şuğullerin, tekkelerde ve dinî meclislerdeki törenlerde herkesin okuyabileceği düzeyde bestelendiği sonucuna ulaşılmıştır.

\section{2. İkinci Alt Probleme İlişkin Sonuçlar}

1. Araştırmaya konu olan Şuğuller TRT Repertuarı, Türkiye Cumhuriyeti Kültür Bakanlığı Arşivi, Devlet Korosu Arşivi ile özel koleksiyonlardan, Düyek usûlünde ölçülmüş olup Rast ve Sabâ makamlarında olanları örneklem olarak seçilmiştir. Örnekleme dâhil olan on dokuz adet Şuğul'ün notaları birçok kaynaktan karşılaştırılarak ve var olanlarının ses kayıtları incelenerek notaların doğruluğu kontrol edilmiştir. Notaları yanlış yazılmış olanlar düzeltilmiştir. 
2. Klâsik Türk Mûsikîsi'nde Düyek usûlünde ölçülmüş Rast ve Sabâ makamlarındaki Şuğullerin bestelerinin ele alınan makamların teorik özelliklerini taşıdığı tespit edilmiştir. Ayrıca çalışılan eserlerde beste-güfte uyumunun yani prozodi kurallarının yer aldığı saptanmıştır.

3. Araştırmaya konu olan Düyek usûlünde ölçülmüş Rast makamındaki on altı adet Şuğul'ün Rast makamının genel karakteristik özelliklerini taşıdığı tespit edilmiştir.

4. Araştırmaya konu olan Düyek usûlünde ölçülmüş Sabâ makamındaki üç adet Şuğul'ün Sabâ makamının genel karakteristik özelliklerini taşıdığı tespit edilmiştir.

5. İncelenen Şuğullerin uzun soluklu nağmelere sahip olmadığı ve bundan dolayı da farklı makam geçkilerine az rastlandığ1 görülmüştür. Şuğullerin form olarak uzun olmamaları, makam geçkisi yapmaya fazla olanak tanımamaktadır. Ancak yine de bazı Şuğullerde bir ya da iki ölçü de olsa makam geçkisi yapıldığ1 görülmüştür. Bazı Şuğullerde ise makam geçkilerine hiç rastlanılmamıştır. Makam geçkisi yapılmış eserlerden bahsetmek gerekirse "Elà Yà Es ade'l-'Evlàd" adlı Rast Şuğul'de Hicâzlı ve Müstearlı geçkiler yapılmıştır. "Eș-Șubḥu Bedā Min Țal'atihi” adlı Rast Şuğul'de Hicâzlı geçki yapılmıştır. "Feșaddaḳnāke Yā Hayra'l-Verā Yā Rasūlallāh" adlı Rast Şuğul'de Hicâzlı geçki yapılmıştır. "Hāz̄ā Ġazālī Mine'l-Yemānī Ve'ş-Şeklu'l Ḥasen” adlı Rast Şuğul'de Hicâzlı geçki yapılmıştır. "Li Ḥażreti’s-Seyyid Er-Rifă‘î” adlı Rast Şuğul'de Hüseynîli geçki yapılmıştır. "Cud Bi Luțfik Yā 'İlāhī Men Lehu Zādün Ḳalīl” adlı Sabâ Şuğul'de Hicâz'lı geçki yapılmıştır.

6. Araştırmaya konu olan Şuğullerin tamamı Arapça güfteli değildir. Bazılarında Farsça kelimelere rastlanılmıştır. Bazılarında ise "Mu'allâ gavsi sübhânî" adlı şuğulde olduğu gibi, çoğunluğu Farsça olan güftelere rastlanılmıştır. Farsça güfteli Şuğuller daha çok Fars ve Osmanlı kökenli güfte sahiplerine aittir.

7. Bazı Şuğullerin güftelerinin Hz. Ömer, Hassan bin Sabit gibi Hz. Muhammed döneminde yaşamış olan kişiler tarafından yazılmış olması, güftelerin günümüze ulaşana kadar bazı değişikliklere uğramış olduğu düşünülmektedir.

8. Araştırma sırasında güfte sözlerinin bazılarının anlamsız olduğu ve yanlış yazıldığı ya da Arapça bilmeyen insanlar tarafından yanlış anlaşılıp yanlış yazıldığı tespit edilmiştir. Bu yanlışlıklar anlam bütünlüğüne ve vezin yapılarına uygun olacak şekilde Arapça olarak düzeltilmiştir.

9. Çalışmaya konu olan Şuğullerin vezin yapılarının hece ve âruz vezinlerinde olduğu tespit edilmiştir. Ancak bazı Şuğuller ne hece ne de âruz vezni kalıplarında değildir. Bu manadaki kayıtlara istinaden bu eserlerin güftelerinin ya eksik yazıldığı ya da vezin usûlü gözetilmeden kaleme alındığı düşünülebilir.

10. Araştırmaya konu olan on dokuz adet Şuğul'ün güftelerinin iki adetinin âruz vezni özelliği taşıdığı tespit edilmiştir.

11. Araştırmaya konu olan on dokuz adet Şuğul'ün güftelerinin on dört adetinin hece vezni özelliği taşıdı̆̆ tespit edilmiştir.

12. Araştırmaya konu olan on dokuz adet Şuğul'ün güftelerinin üç adetinin herhangi bir âruz veya hece vezni kalıbına uyum sağlamadığı tespit edilmiştir. Bu durumun, güftelerin günümüze ulaşıncaya kadar çeşitli değişikliklere uğramış olacağı ihtimalinden kaynaklandığı düşünülmektedir.

\section{3. Öneriler}

1. Klâsik Türk Mûsikîsi alanında müzikologlar tarafından yapılacak çalışmalarda, diğer formların günümüze ulaşan eserlerinin tasnif ve tespit bağlamında ele alınarak incelenebilir.

2. Çeşitli kaynaklarda Klâsik Türk Din Mûsikîsi eserlerinin sayılarının bilinenden daha fazla olduğuna değinilmektedir. Bahsedilen bu unutulmuş, belge ya da kayıtları olmayan eserler üzerinde kapsamlı araştırma çalışmaları yapılmasının, bu eserlerin repertuvar arşivlerine kazandırılması açısından önemli olacağı düşünülebilir. 
3. Çalışmaya konu olan Şuğullerden başka diğer araştırmacılar tarafindan diğer makamlardaki eserlerin de analizlerinin yapılmasının, Şuğul formunun daha detaylı anlaşılması konusunda fayda sağlayacağı düşünülebilir.

4. Şuğullerin, çeşitli arşivlerde derlenmiş bir şekilde, daha ayrı müstakil bir form olarak takım haline getirilmesi; mevcut olan Şuğullerin ulaşılabilirliği ve sayılarının kontrol altına alınması açısından faydalı olacağı düşünülebilir.

5. Şuğullerin, Arapçaya hâkim mütehassıslar tarafından müzikolog iş birliği ile tekrar kaleme alınması manânın ve veznin ortaya çıkması açısından faydalı olacağı düşünülebilir.

6. Bu çalışma sonrası çeşitli makaleler ele alınarak, Şuğul formu üzerinde kapsamlı bir çalışma yapılabilir. Şuğul formunun genel olarak İlâhî formuna uyduğu bilindiğinden, Şuğullerin İlâhî formundan tek farkının güftelerinin Arapça olmasının dışında başka farklılıklarının da olup olmadığı araştırılabilir.

7. Günümüzde en son bestelenen Şuğullerin, Cinuçen Tanrıkorur tarafından bestelendiği bilinmektedir. Günümüzde Şuğul formu bestekârlı̆̆ının devam edip etmediği araştırılabilir.

8. Araştırmamızda Şuğullere ait güftelerin aruz ve hece vezni kurallarını ihlâl ettiği saptanmıştır. Bu farklılığın sebebi araştırılabilir, bu bağlamda diğer formlardaki güftelerin de analizleri yapılarak bu paralelde bir sebep-sonuç ilişkisine ulaşılabilir.

9. Günümüzde Klâsik Türk Mûsikîsi eğitimi veren kurumlarda Şuğul formuna ait eserlerin daha çok öğretilmesi, gelecek nesiller açısından Şuğul formunun unutulmaması açısından faydalı olacağı düşünülmektedir. Bu bağlamda, bugün karşılaşılan güfte ve vezin sorunlarının da asgari düzeye ineceği sonucuna ulaşılabilir.

10.Şuğul icra etme geleneğinin çeşitli mûsikî meclislerinde eski dönemlerde olduğu gibi bayramlarda ve dinî günlerde icra edilmesi, bu geleneğin yaşatılması ve sürdürülmesi açısından faydalı olacağı düşünülebilir.

\section{Kaynakça}

Akdoğan, B. (2010). Türk din mûsikîsi dersleri. Ankara: Bilge Matbaası.

Altıntop, M. E. (1994). Türk din mûsikîsinde Arapça güfteli ilâhîler (Şuğuller) (Yüksek Lisans Tezi). YÖK tez veri tabanından erişildi (Tez no: 31752 ).

Aybars, B. (2011). Türk mûsikîsi temel bilgileri. Ankara: İkinci Adam Yayınları.

Çakar, Ş. Ş. (2004). Türk müziği teorisi ve makamlar. Ankara: Milli Eğitim Bakanlığı Yayınları.

Demirtaş, Y. (2009). Türk din mûsikîsi formları. Fırat Üniversitesi İlâhiyat Fakültesi Dergisi, 14 (1), 213-227.

Devellioğlu, F. (2012). Osmanlıca-Türkçe ansiklopedik lûgat. Ankara: Aydın Kitabevi Yayınları.

Karadeniz, E. (2013). Türk mûsikîsinin nazariye ve esasları. İstanbul: İş Bankası Kültür Yayınları.

Karakaya, İ. (2009). Bilimsel araştırma yöntemleri. Abdurrahman Tanrı̈ğen (Ed.). Bilimsel Araştırma Yöntemleri (s. 57-84) içinde. Ankara: Anı Yayıncılık.

Karasar, N. (2005). Bilimsel araştırma yöntemleri. Ankara: Nobel Yayınları.

Kaya, A. (2003). Ney metodu. İstanbul: Çağlar Mûsıkî Yayınları.

Özkan, İ. H. (2010). Türk mûsikîsi nazariyatı ve usûlleri kudüm velveleleri. İstanbul: Ötüken Neşriyat A.Ş. Yayınları.

Tanrıkorur, C. (2003). Osmanlı dönemi Türk mûsikîsi. İstanbul: Dergâh Yayınları. 